О. Ф. Якимчук, керівник групи розрахунків відділу бізнес-систем департаменту інформачійних технологій та телекомунікачій ПрАТ "Рівнеобленерго", аспірант, Начіональний університет водного господарства та природокористування, м. Рівне, Украӥна

ORCID ID: 0000-0002-0960-8835

DOI: $10.32702 / 2306-6814.2019 .8 .136$

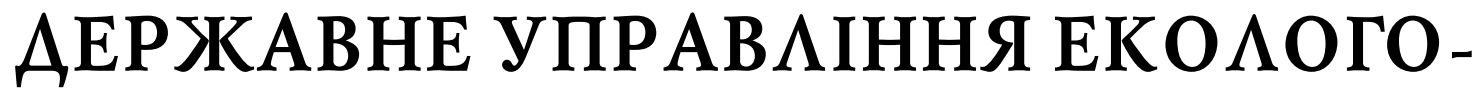 ЕКОНОМІЧНОЮ БЕЗПЕКОЮ В УМОВАХ КАIМАТИЧНИХ ЗМІН: АСПЕКТИ ІНФОРМАТИЗАЦІї
}

\author{
O. Yakymchuk, \\ Head of the Group of CalcPulations of Business Systems Division of the Information Technologies \\ and Telecommunications Department of PJSC "Rivneoblenergo", Postgraduate Student, \\ National University of Water and Environmental Engineering, Rivne, Ukraine
}

\section{STATE MANAGEMENT OF ECOLOGY-ECONOMICAL SAFETY IN THE CONTEXT OF CLIMATE} CHANGES: ASPECTS OF INFORMATIZATION

Кліматичні зміни особливо останнім десятиліттям стали невід'ємною частиною нашого життя. Їх вплив на соціально-економічний розвиток держави доволі вагомий, але оцінити наслідки від зміни клімату повною мірою нині неможливо. Ці зміни позначаються не лише на стані соціально-економічного розвиткудержави, але й упоказниках еколого-економічної безпеки. Тому важливою складовою національної безпеки України, що вказує на зв'язок між економічною могутністю країни, національною безпекою та наявним потенціалом, є її економічна безпека, досягти яку можливо шляхом реалізації форм й методів економічної політики, спрямованої на ефективну діяльність усіх підрозділів та підсистем, первинною ланкою яких є суб 'єкти господарювання. Лише за наявності достовірного інформаційного забезпечення щодо діяльності суб'єктів господарювання стає можливим ефективне управління еколого-економічною безпекою держави. Нині до системи безпеки потрібно закладати інструменти формування інформаційного суспільства, що особливої актуальності набуває в умовах гібридної війни. Все це сформувало мету, предмет та об'єкт цього дослідження. Надзвичайно актуальною є проблема змін і деградації екосистем і грунтів, тобто відновлювальної здатності природних екосистем і відтворення ресурсів. Нераціональне землекористування в умовах кліматичних змін, ігнорування довготривалих змін та концентрація, в основу якої покладено "швидкі прибутки", призводять до виснаження ресурсів й, відповідно, до економічних втрат. Ці втрати полягають у зменшенні родючості грунтів, опустелюванні, ерозії тощо. Нині людство опинилося перед реальною загрозою втратити 25\% продуктивності грунтів. Варто зазначити, що кліматичні зміни спричиняють і значні фінансові витрати для держав. Як підсумок дослідження, автором розроблено комплекс заходів задля зміцнення еколого-економічної безпеки України, окреслено перспективи впровадження концепції сталого розвитку в умовах зміни клімату. Нова система державного управління забезпеченням інформаційної безпеки України повинна грунтуватися на врахуванні запропонованих концептуальних засад забезпечення еколого-економічної безпеки.

Climate change in recent years has become an integral part of our lives. Its influence on the socioeconomic development of the state is rather significant, but it is impossible to assess the consequences of climate change to the full extent. These changes affect not only the state of socio- 
economic development of the state, but also indicators of ecological and economic security. Therefore, an important component of Ukraine's national security, which indicates the link between the country's economic power, national security and available potential, is its economic security, which can be achieved through the implementation of forms and methods of economic policy aimed at the effective operation of all units and subsystems, the primary the link of which are business entities. Only in the presence of reliable information support regarding the activities of economic entities has been possible to effectively manage the state's economic security. Today, the security system should be equipped with tools for the formation of the information society, which becomes especially relevant in the context of the hybrid war. All this formed the actuality, purpose and object of this investigation. Extremely urgent are the problems of changes and degradation of ecosystems and soils, that is, the renewable capacity of natural systems and the reproduction of resources. Inappropriate land use in climate change, ignoring long-term changes, and concentrating on rapid returns lead to resource depletion: fertility loss, desertification, erosion, etc. One can say that mankind faced a real threat in 15-20 years to lose $25 \%$ of soil productivity. It is worth noting that climate change also entails significant financial costs for states. A set of measures for strengthening of ecological and economic security has been developed, prospects of implementation of the sustainable development concept in conditions of climate change have been ordered. The new system of state management of providing information security of Ukraine should be based on the proposed conceptual framework for the provision of environmental and economic security.

Ключові слова: інформатизація, еколого-економічна безпека, законодаßстВо, міжнародна співпраця, розВиток.

Key words: informatization, ecology-economical safety, legislation, international activity, development.

\section{ПОСТАНОВКА ПРОБАЕМИ}

Кліматичні зміни в останні роки стали невід'ємною частиною нашого життя. Їх вплив на соціально-економічний розвиток держави доволі вагомий, але оцінити наслідки від зміни клімату повною мірою нині неможливо. Ці зміни позначаються не лише на стані соціально-економічного розвитку держави, але й у показниках еколого-економічної безпеки. За даними міжнародних організацій, зокрема, організації Christian Aid, лише у 2018 році екстремальні погодні явища, пов'язані зі зміною клімату, забрали тисячі життів і завдали величезної шкоди у всьому світі. У доповіді цієї благодійної організації визначено десять подій, шкода від яких перевищила 1 мільярд доларів. Шкода від чотирьох з них становила понад сім мільярдів доларів [1].

Як стверджують експерти, періоди надзвичайної спеки в Європі були безпосередньо пов'язані із діяльністю людини, що призвела до глобального потепління. Інші події, пов'язані зі зміною погодних умов, які, як вважається, є наслідком зміни клімату. Згідно з доповіддю Christian Aid, найбільшу шкоду серед подій, пов'язаних зі збільшенням температури, завдали урагани "Флоренс" та "Майкл" - 17 та 15 млрд доларів відповідно. Адже як показали дослідження, опади, які супроводжували ураган "Флоренс", були на 50\% потужніші, аніж у випадку, якби на їхню кількість не впливало потепління, зумовлене діяльністю людини. А щодо урагану
"Майкл", стверджують дослідники, діяльність людини призвела до викидів, які зробили воду теплішою, і додали урагану швидкість. У Японії літо 2018 року супроводжувалося повенями та спекою, які мали великі негативні наслідки. За розрахунками, повені завдали шкоди на понад 7 млрд доларів, а за ними прийшов тайфун Джебі, найпотужніший за 25 років [1].

Важливою складовою національної безпеки України, що вказує на зв'язок між економічною могутністю країни та наявним природно-ресурсним потенціалом, $\epsilon$ іiї еколого-економічна безпека. В сучасних умовах досягти високого рівня еколого-економічної безпеки можливо шляхом реалізації форм й методів економічної політики, спрямованої на ефективну діяльність усіх підрозділів й підсистем, первинною ланкою яких є суб'єкти господарювання. Лише за наявності достовірного інформаційного забезпечення щодо діяльності суб'єктів господарювання ефективне управління економічною безпекою держави стає можливим.

Нині внаслідок розгортання гібидної війни в Україні, впливу воєнно-політичних фракторів, виникло складне економічне становище, відбувся обвал національної валюти, зазнала деформації промислова інфраструктура східного регіону. Все це в сукупності становить неймовірно високу загрозу економічній безпеці держави. У цьому ракурсі важливим $є$ кожен елемент складної системи національної економіки. Сьогодні стан еконо- 
Таблиця 1. Збитки держав від глобального потепління у випадку зростання викидів $\mathrm{CO}_{2}$ удвічі, млрд дол.

\begin{tabular}{|l|l|l|l|}
\hline $\begin{array}{c}\text { № } \\
\text { 3/п }\end{array}$ & \multicolumn{1}{|c|}{ Країна (регіон) } & $\begin{array}{c}\text { Економічнй } \\
\text { збиток, млрд. } \\
\text { дол. США }\end{array}$ & $\begin{array}{c}\text { У \% до } \\
\text { ВВП } \\
\text { держави }\end{array}$ \\
\hline 1. & $\begin{array}{l}\text { Україна і країни } \\
\text { колишнього СНД }\end{array}$ & 7,9 & 0.3 \\
\hline 2. & Європа & 63,6 & 1,4 \\
\hline 3. & США & 61,0 & 1,3 \\
\hline 4. & Китай & 18,0 & 5,2 \\
\hline 5. & Південна Азія & 53,5 & 8,6 \\
\hline 6. & Африка & 30,3 & 8,7 \\
\hline 7. & Латинська Америка & 31,0 & 4,3 \\
\hline 8. & Росія & 18,2 & 0.7 \\
\hline 9. & Середній Схід & 1,3 & 4.1 \\
\hline & Всього & 284,8 & 1,9 \\
\hline
\end{tabular}

Джерело: адаптовано за [1; 4].

мічної системи нашої держави певним чином підтримують міжнародні організації - переважно за рахунок надання міжнародних кредитів. Пріоритетним напрямом зовнішньополітичної діяльності є ратифікація угоди із $€ C$. Співпраця зі міжнародними організаціями ставить перед Україною низку вимог, серед яких - прозорість фрінансових потоків. Чітка регламентація інформаційного забезпечення, його здатність формувати аналітичні показники, $є$ актуальним завданням для достовірного й прозорого управління системою еколого-економічної безпеки держави.

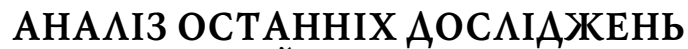 І ПУБ $А$ КАЦІЙ}

Існує чисельна кількість наукових публікацій із проблем безпеки. Більшість із них стосується визначення сутності й механізмів забезпечення національної безпеки, економічної й фрінансової безпеки підприємств, соціальної й особистісної безпеки, екологічної безпеки держави, регіону. Зокрема систему економічної безпеки держави досліджували такі вчені: Г. Андрощук, Т. Васильців, В. Геєць, Н. Гуськова, Л. Донець, В. Ліпкан, В. Іванов, Я. Жаліло, М. Камлик, А. Козаченко, О. Кизим, Ю. Лисенко, О. Ляшенко, В. Мунтіян, О. Прокопенко, М. Петрушенко, Н. Реверчук, І. Татаркіна, А. Скопіна та інші. Ці вчені сорормували теоретико-методологічні засади оцінки економічної безпеки держави, підприємства, обгрунтували механізми й окремі інструменти управління економічною безпекою, окреслили пріоритетні напрями забезпечення економічної безпеки держави.

Проблемам екологічної безпеки присвятили дослідження Є. Хлобистова, О. Радченка, Гончарова, В. Ковтун, Б. Данилишина, Е. Олейнікова, В. Степанова, С. Харічкова, М. Хвесика, А. Якимчук та інші. Названі вчені екологічну безпеку загалом розглядють як складову національної безпеки. Акцент із позиції поставлено на усуненні екодеструктивного впливу підприємства на навколишнє природне середовище (НПС), середовище людської життєдіяльності.

Попри вагомі напрацювання вчених, динамічність розвитку економічних систем, їх оточення, технологій, сфрери діяльності обумовлюють доцільність подальших досліджень. Окрім того до системи еколого-економічної безпеки мають бути закладені інструменти формування інформаційного суспільства, що особливої актуальності набуває в умовах гібридної війни. Все це сорормувало мету, предмет та об'єкт даного дослідження.

\section{ПОСТАНОВКА ЗАВААННЯ}

Дослідити процес державного управління екологоекономічною безпекою України в умовах кліматичних змін й розробити рекомендації щодо його удосконалення на основі впровадження заходів із посилення інформатизації суспільства.

\section{ВИКААА ОСНОВНОГО МАТЕРІААУ}

Нині комплексно оцінювати стан економічної безпеки держави дозволяє розроблена й затверджена Міністерством економіки України "Методика розрахунку рівня економічної безпеки" [2]. У цьому документі розглянуто основні дефініції в сфрері економічної безпеки України й встановлено методику розрахунку інтегрального індексу економічної безпеки на основі значень понад сотні індикаторів, які згруповано відповідно до окремих складових економічної безпеки. Складовими економічної безпеки є: виробнича, демографічна, енергетична, макроекономічна, інвестиційно-інноваційна, продовольча, соціальна, зовнішньоекономічна, фрінансова безпеки.

Науковий і практичний інтерес становить питання співвідношення понять "кліматичні ризики" й "національна безпека". Винесення цих питань на широку суспільну дискусію має сприяти мобілізації політичних еліт i, зрештою, ухваленню відповідних рішень в галузі національної безпеки. Сьогодні найбільшою проблемою $€$ ескалація надзвичайних ситуацій, пов'язана із кліматичними змінами. Незважаючи на повільний характер "середніх" змін, критично і суттєво змінюються екстремальні (максимальні і мінімальні) показники, і саме вони, зазвичай, відповідальні за генезис надзвичайних ситуацій [3]. Варто звернути увагу на той факт, що кліматичні ризики досить прогнозовані. Зокрема очевидно, що підвищується ризик як осінніх, так й весняних паводків і підтоплень за рахунок збільшення кількості і зміни структури опадів. Підвищуються ризики ландшафртних пожеж. За оцінками фрахівців [5-8] ризики пожеж на наступні 15-20 років зростуть удвічі.

Надзвичайно актуальними є проблеми змін і деградації екосистем і грунтів, тобто відновлювальної здатності природних систем і відтворення ресурсів. Нера- 
Таблиця 2. Підходи щодо трактування поняття "безпека"

\begin{tabular}{|l|l|}
\hline \multicolumn{1}{|c|}{ Підхід } & \multicolumn{1}{|c|}{ Зміст } \\
\hline Пасивний & $\begin{array}{l}\text { Дотримання певних параметрів та норм, від } \\
\text { забезпечення яких безпосередньо залежить безпека }\end{array}$ \\
\hline Апофатичний & Безпека як відсутність загроз і небезпек \\
\hline Статистичний & Безпека як стан захищеності \\
\hline Діяльнісний & $\begin{array}{l}\text { Система заходів, спрямованих на створення певних } \\
\text { безпечних умов }\end{array}$ \\
\hline
\end{tabular}

Джерело: сорормовано за [5, с. 362-363].

ціональне землекористування в умовах кліматичних змін, ігнорування довготривалих змін та концентрація на швидкому прибутку призводять до виснаження ресурсів: втрат родючості, опустелювання, ерозії тощо. Можна сказати, що людство опинилося перед реальною загрозою через 15-20 років втратити 25\% продуктивності грунтів [4-6; 11]. Варто зазначити, що кліматичні зміни спричиняють і значні фінансові витрати для держав. Розмір економічних збитків різних країн як у вартісному, так й у відсотковому до ВВП виразі репрезентовано у таблиці 1.

Отже, як свідчать дані таблиці, більшість держав мають значні економічні збитки від зміни клімату, найбільші відмічено у країнах Європейського Союзу 63,6 млрд дол., у США - 61 млрд дол., країнах Південної Азії 53,5 млрд дол.

Важливою загрозою є проблеми деградації водних ресурсів, пов'язані із змінами водного режиму, виснаженням, забрудненням через надлишкове антропогенне навантаження. Україна - вододефіцитна держава вже впродовж більш як 40 років. І проблеми наявності й доступності водних ресурсів будуть і надалі зростати. Некоординовані, ситуативні стратегії водокористування, кон'юнктурні рішення в галузі управління водними ресурсами можуть поставити під загрозу не лише господарство, але й життя населення в цілих регіонах. За інтегральними підрахунками, впродовж найближчих 15-20 років, кількість доступних водних ресурсів у нашій країні може зменшитися втричі [9].

Український вчений В.А. Ліпкан здійснив типізацію поняття "безпека" та виділив чотири підходи щодо його трактування, що дає можливість розглядати безпеку як специфічну властивість динамічних систем і як комплексний критерій оцінки її якості, що характеризує динаміку розвитку системи (табл. 2) [5].

3 розвитком понятійного апарату теорії безпеки розвивався і розширювався зміст наук, що займалися проблемами досягнення безпеки людини, суспільства й держави. За умов постійної присутності загроз від сторонніх осіб та держав, безпека стає метою, яка визначає діяльність урядів держав.

Таким чином узагальнення й систематизація зарубіжного досвіду державного управління забезпеченням інформаційної безпеки дозволяє констатувати, що державне управління забезпеченням інформаційної безпеки України повинно грунтуватися на врахуванні відповідних концептуальних засад захисту і наступу в цій галузі, а також необхідно мати для цього відповідні політичні, економічні й технічні можливості. При цьому слід враховувати культурно-цивілізаційні особливості суб'єктів інформаційно-психологічного протиборства, адже релігія і культура, а також підсвідоме архе, яке лежить в їхній основі, не менш важливі для сучасних стратегій взаємодії та впливу, ніж досить очевидні промислові та фрінансові реалії життя [6; 7].

Також необхідно пам'ятати, що сьогодні відбувається зміна парадигми глобального інформаційно-психологічного протиборства, яка вже успішно проявила себе в методах, технологіях і механізмах концепції "стратегічних комунікацій". Більшість розвинених країн вже перебудовують власні системи державного управління інформаційної безпеки, оскільки розуміють, що це виведе їх на принципово новий рівень ефективності у досягненні власних інтересів на міжнародній арені. Нині в Україні також вже починають усвідомлювати важливість стратегічних комунікацій як ефективного інструменту для протидії негативних інформаційно-психологічних впливів, про що свідчить законодавче закріплення таких понять, як "стратегічні комунікації" й "стратегічний наратив" у Воєнній доктрині України та новій Доктрині інформаційної безпеки України.

Отже, на етапі переходу суспільства до сталого розвитку економічна парадигма цінності навколишнього середовища відіграє свою позитивну роль. 3 метою попередження негативних наслідків від деградації навколишнього середовища необхідна нова екологічно спрямована стратегія. Актуальним питанням сьогодення $\epsilon$ формування системи управління еколого-економічною безпекою як держави в ціому, так й її регіонів. Причиною цього $\epsilon$ негативні екологічні наслідки від господарської діяльності. Це примушує підприємства фоормувати систему управління екологічної безпеки. Ефективна система екологоорієнтованого управління має відповідати вимогам якісної перебудови екологічного регулювання та дійового економічного механізму екологобезпечної діяльності.

\section{ВИСНОВКИ}

Стосовно України перспективним $€$ визначення нової ролі держави за умов загострення екологічних проблем ії розвитку на регіональному рівні. Останнє десятиліття показало, що відкидати адміністративні можливості у цій сорері передчасно. Без ефективного управління, адміністративного контролю і впливу неефективно працюють і економічні важелі забезпечення екологічних вимог у господарській діяльності регіонів. На державному рівні потрібно забезпечити інтеграцію екологічної складової у стратегію проведення соціально-економічних реформ. Идеться про посилення у суспільстві мотивації для врахування вимог еколого-економічної безпеки під час складання й втілення соціально-економічних планів розвитку; впровадження методики розрахунків економічної ефективності природоохоронних заходів; ліцензування небезпечних видів діяльності як інструменту регулювання рівня безпеки під час використання небезпечних речовин; екологічне страхування як механізм 
сприяння вирішенню проблем екологічної безпеки; оцінку екологічного ефректу під час інвестування у економічний сектор задля переходу на інноваційну модель розвитку; запровадження екологічного аудиту як одного із важливих інструментів оцінки рівня безпеки; застосування поняття "ризик" як інтегрального показника можливих екологічних загроз; вдосконалення економічних механізмів природокористування, які б були органічно пов' язані із інструментами соціально-економічного регулювання життєдіяльності суспільства в умовах ринкової економіки; удосконалення системи штрафрних санкцій за заподіяння шкоди навколишньому природному середовищу та економічні правопорушення. Державне управління забезпеченням інформаційної безпеки України повинно грунтуватися на врахуванні відповідних концептуальних засад реалізації належної системи еколого-економічної безпеки. Нині необхідно мати відповідні політичні, економічні й технічні можливості. При цьому слід враховувати культурно-цивілізаційні особливості суб'єктів інформаційно-психологічного протиборства, які $\epsilon$ не менш важливими у розробленні сучасних стратегій взаємодії та впливу, аніж досить очевидні промислові та фрінансові реалії життя.

Необхідно створити механізм організації злагодженої роботи фрахівців, як з державних служб, так й неурядових організацій щодо питань ведення інформаційної війни, удосконалити нормативно-правовову базу у сорері інфрормаційної безпеки, особливо звертаючи увагу на питання, щодо залучення громадянського суспільства до заходів забезпечення інформаційної безпеки.

\section{Література:}

1. Кліматичні зміни: скільки коштувало людству глобальне потепління у 2018 році [Електронний ресурс]. Режим доступу: https: // www.bbc.com / ukrainian/ features-46697228

2. Стратегія національної безпеки України "Україна у світі, що змінюється": затв. указом Президента України від 08.06.2012 №389/2012 [Електронний ресурс]. - Режим доступу: http://zakon4.rada.gov.ua/laws/ show $/ 389 / 2012$

3. Про затвердження Методичних рекомендацій щодо розрахунку рівня економічної безпеки України: наказ Міністерства економічного розвитку і торгівлі України № 1277 від 29.10.2013 [Електронний ресурс]. Режим доступу: https://ips.ligazakon.net/document/ view/ME131588

4. Кліматичні зміни складають загрозу національній безпеці [Електронний ресурс]. - Режим доступу: https://www.radiosvoboda.org/a/25139156.html.

5. Ліпкан В.А. Теорія національної безпеки: [підручник] / В.А. Ліпкан. - К.: КНТ, 2009. - 631 с., с. 362-363.

6. Бобров Є. Сучасні підходи до дослідження економічної безпеки / Є. Бобров / / Економіка України. -2012 . - № 4. - С. $80-85$., с. 80.

7. Шершун М.Х., Дребот О.І. Економіка природокористування лісових екосистем: навч. Посіб. - К.: ДІА, 2017. - 264 с.

8. Щодо затвердження Базового плану адаптації екологічного законодавства України до законодавства Європейського Союзу (Базовий план апроксимації).
Наказ від 17.12.2018 № 659 // http://www.menr. gov.ua/index.php/normakty/60-9/acts

9. Належне екологічне врядування в країнах Східного Партнерства: роботи непочатий край. [Електронний ресурс]. Режим доступу: https://eu.prostir.ua/files/ $1331819362039 /$ Environmentalgovernance_PB_15.03_ukr.pdf

10. Перелік директив та регламентів у сорері охорони навколишнього середовища [Електронний ресурс]. Режим доступу: https://www.google. com/search

11. Якимчук А.Ю. Економічний та управлінський аспекти збереження біорізноманіття України за вимогами Кіотського протоколу / А.Ю. Якимчук // Вісник ЛНТУ України. - Львів, 2014. - № 24.02. - С. 131142.

\section{References:}

1. BBC (2019), "Climate change: how much global warming would cost humanity in 2018", available at: https://www.bbc.com/ukrainian /features-46697228 (Accessed 02 Apr 2019).

2. President of Ukraine (2012), Decree "Ukraine's National Security Strategy "Ukraine in a Changing World ", available at: http://zakon4.rada.gov.ua/laws/show / 389/2012 (Accessed 02 Apr 2019).

3. Ministry of Economic Development and Trade of Ukraine (2013), "On Approval of Methodological Recommendations for Calculating the Level of Economic Security of Ukraine", available at: https://ips.ligazakon.net/document/view/ME131588 (Accessed 20 Jan 2019).

4. Radio svoboda (2019), "Climate change is a threat to national security", available at: https://www.radiosvoboda.org/a/25139156.html (Accessed 02 Apr 2019).

5. Lipkan, V.A. (2009), Teoriia natsional'noi bezpeky [The theory of national security], KNT, Kyiv, Ukraine.

6. Bobrov, E. (2012), "Modern Approaches to the Study of Economic Security". Ekonomika Ukrainy, vol. 4, pp. $80-85$.

7. Shershun, M. and Drebot, O. (2017), Ekonomika pryrodokorystuvannia lisovykh ekosystem [The economics of forest ecosystem use], DIA, Kyiv, Ukraine.

8. Ministry of Ecology and Nature Resources Usage (2018), "On approval of the baseline environmental adaptation of Ukraine's legislation to the European Union (Baseline approximation)", available at: http:// www.menr.gov.ua/index.php/normakty/60-9/acts (Accessed 20 Jan 2019).

9. Humeniuk, V. and Mischuk, Z. (2012), "Good environmental governance in the Eastern Partnership countries: the work is endless", available at: https:// eu.prostir.ua/files/1331819362039/Environmentalgovernance_PB_15.03_ukr.pdf (Accessed 02 Apr 2019).

10. Google.com (2019), "List of directives and regulations in the field of environmental protection ", available at: https://www.google.com/search (Accessed 02 Apr 2019).

11. Yakymchuk, A. (2014), "Economic and managerial aspects of biodiversity conservation of Ukraine according to the requirements of the Kyoto Protocol", Visnyk LNTU Ukrainy, vol. 24.02, pp. 131-142.

Стаття надійшла до редакиї 02.04.2019 p. 